Исидора Ана Стамболић Градски музеј Суботица https://doi.org/10.18485/ai_most.2017.ch19 isidora.ana@gmail.com

\title{
ВЕЗЕ ИЗМЕЂУ ТРАДИЦИОНАЛНЕ КУЛТУРЕ И СРПСКИХ ПРЕВОДА СРЕДЊОВЕКОВНИХ АПОКРИФА
}

У овом раду ћемо покушати да укажемо на евентуалне аналогије које се могу уочити између одређених текстуалних сегмената српских средњовековних апокрифа и традиционалне културе. 3бог обима и сложености теме, нисмо настојали да побројимо и анализирамо све такве постојеће везе, већ смо изабрали неколико упечатљивих и погодних мотива за јасно указивање повезаности две поменуте традиције. Тако смо се одлучили да изнесемо неке тезе у вези са простором, мотивом змаја, змије и ђавола који се на сличан начин приказују и дочаравају у апокрифној и народној традицији.

Кључне речи: апокриф, традиционална култура, простор, ђаво, змија, змај

Приличан део преводне средњовековне књижевности са којом су Срби долазили у везу припадао је апокрифима. Број преписа који је сачуван говори нам да се такав вид књижевности одомаћио код Словена и прилагођавао њиховом сензибилитету и занимањима. (Види: Јовановић 2005а: 9-10) Упркос томе једна од најмање истраживаних тема, из области књижевности српског средњег века јесу апокрифи ${ }^{1}$. Први индекси (спискови)

За Источну цркву, апокрифи су књиге (сем Септуагинте) које сматрају јеретичким, лажним. Пре II и III века тј. пре кано- 
забрањених књига ${ }^{2}$ јављају се у току IV века, а у њима су апокрифи посебно обрађивани. Томислав Јовановић, као најстарији сачувани попис забрањених књига код Словена, помиње онај који се налази у руском Свјатиославовом изборнику из 1073. године. Донка Петканова-Тотева наводи најранији словенски индекс забрањених књига под називом Поїоgинов инgекс ${ }^{3}$ који садржи у себи апокрифна житија и молитве. У Кииријановом индексу, који потиче са краја XIV и почетка XV века, забрањују се сујеверне књиге, које немају тематске везе са Библијом. Он их изједначава са апокрифима, који су, такође, део забрањене литературе. Временом су се под појмом апокрифа подразумевале све варијације на библијску тематику, али и књиге које се нису тицале библијског учења, већ су на неки начин проповедале народна сујеверја.

„Од посебне, не само терминолошке важности, јесте питање одређења шта јесте, а шта није апокриф. Уобичајено се под овим појмом подразумевају прозни књижевни списи

низације, однос према апокрифима је био веома слободан и отворен. Неки писци, попут Оригена и Јосифа Флавијског, сматрали су их корисним делом религиозне литературе. Након канонизације и проглашења хришћанства за државну религију Римског царства, црква настоји да дефинише своје проповедање и утврди његову јединственост и једнообразност. Стога, све књиге које се разликују према обрасцу, идеји, причи у односу на канонске књиге проглашава јеретичким и лажним.

2 Први византијски тип таквог индекса је написао Исидор Пелусиот, пописавши шездесет дозвољених и осам недозвољених књига. Крајем V века папа Григорије издаје списак одбачених књига.

3 Питањем забрањених књига у словенским преводима и преписима бавили су се многи истраживачи и то занимање траје више од једног века. Тако је настала обимна литература која показује да спискови забрањених књига имају вишеструк значај у проучавању апокрифа. Томислав Јовановић у том пољу изучавања посебно издваја радове Александра Николајевича Пипина, Ватрослава Јагића, Михаила Несторовича Сперанског, Александра Ивановича Јацимирског, Боњу Ангелова, Ивана Дујчева... (Јовановић 2005а: 15) 
који обухватају библијске личности и теме, интерпретиране на нешто другачији, углавном маштовитији, начин,

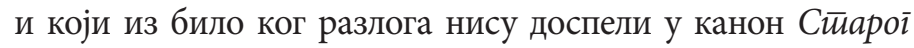
или Новоі заветиа. Ипак, у њиховом поимању често долази до појмовног проширења, на све оно што је апокрифно. Држећи се основног значења апокрифа, за ову прилику усредсређујемо се само на неканонске списе наративног типа у којима се појављују библијске личности. По страни остају састави који припадају апокрифним молитвама, апокрифним питањима и одговорима, гатарским врстама, као што су громовник, коледник, луновник, сановник, трепетник, који се у оквиру апокрифних списа појављују на списковима забрањених књига код Јужних Словена најпре током XIV века“. (Јовановић 2005а: 11)

Заједничко постојање апокрифа и народних веровања у индексима забрањених књига указује на сличан однос према свету, две засебне традиције. Оно што примарно примећујемо јесте да апокрифи као и народна веровања покушавају да недоречено и необјашњиво објасне на сликовит и народу разумљив начин. Народна традиција и апокрифна проза преплићу се, дакле, на местима која су погодна за слободоумно домишљање и боље разумевање религиозних појава, космогонијског уређења итд. Када говоримо о фантастици у апокрифима, морамо имати у виду да је она настала на темељу библијских предања. Међутим, при преводима и преписима у њих су интерполирани елементи народне традиције ${ }^{4}$, те се фабула одвија у библијском контексту са примесама народних предања и веровања ${ }^{5}$.

4 Везу између апокрифа и народне традиције нагласио је и Т. Јовановић сматрајући да апокрифи у себи чувају разнолику културну традицију и обиље легенди и обичаја бројних народа. (Јовановић 2005а: 12)

5 Видно је разгранатија фантастика у старозаветним, него у новозаветним апокрифима. Такво стање је вероватно проузроковано самом природом приче којом се баве старозаветни апокрифи. 


\section{1. Простор у српским средњовековним апокрифима и традиционалној култури}

Приметна је веза апокрифа и традиционалне културе у просторној организацији микро и макрокосмоса ${ }^{6}$. Фантастични свет у апокрифима, као и у народној традицији подразумева просторне компоненте које су строго симболички дефинисане. У традиционалној култури простор је увек схваћен хетероген и често се поима у оквиру бинарних опозиција. Међу најопштијим поделама простора у културама народа спада она која је исказана разликовањем „омеђеног“, тј. „свог“ или тзв. цивилизованог простора и „туђег“, тј. простора који човек није уредио. Дакле, човек сигурним простором сматра онај који је обележио својим деловањем и који је под заштитом богова којима се моли, док преостали простор припада оностраном. Тако кућа, град, храм припадају човековом сигурном простору, док су нпр. вода, гора и друга природна пространства потенцијално опасан простор (Детелић 1992), јер су под влашћу оностраних сила7. Осим „свог“ и „туђег“ простора, традиционални човек познаје и гранични простор у коме мора да се влада по одређеним правилима, у супротном и он постаје потенцијално опасан 8

Настанак и одржавање постојања света, настанак одређених ствари, митске животиње итд. појављују се у старозаветним апокрифима у склопу прича које у канону не постоје, или су мотиви готово успутно поменути. Радознао верник очигледно је имао потребу да приближи себи одређене библијске приче и да их оживи сликовитијим фантастичним светом.

6 Занимљива представа простора и времена у народним бајкама дата је у књизи Немање Радуловића Слика светиа у срйским народним бајкама (2009).

7 Стога се често при истеривању нечисте силе одиграва својеврсно слање у „тућ“"простор, нпр. иди „у гору“, „у брдо“, „у планину“, „у пусто село“" итд.

8 Посебно је занимљива и семантизација леве и десне стране простора, која се може уочити и у апокрифној грађи при просторној организацији нечистих сила. 
У српским средњовековним апокрифима свет се дели на два или три дела, у зависности од позиционирања „предела зла“. У неким апокрифима, као што су Варухово ойкровене или Кюиїа о Еноху, ђаво и његово царство је смештено на једном од седам небеса, а не у подземљу,

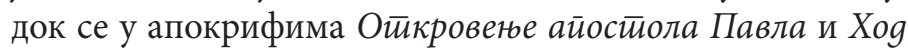
Боїороguще йо мукама указује на постојање пакла/хада и ђавола, али њихово подредиште није сасвим јасно. Некада се чини да се налазе на небу, на западној страни, некад на земљи, док су у појединим тренуцима ђаволи смештени у међупростору земље и неба. Изузетну важност и симболичку снагу у просторној организацији света апокрифа има вода ${ }^{9}$ (уже море или река). Вода је у многим митовима елемент који се помиње на самом почетку стварања света. Драгољуб Драгојловић наглашава да је код предњеазијских народа основна природна стихија вода, да из ње настају прва божанства која започињу космогонијски процес. Мирча Елијаде када говори о космологији и космогонији алтајских народа помиње устаљен и уопштен пејзаж стварања човека у коме је вода основни елемент. (Елијаде 1991: 9). Уколико се присетимо

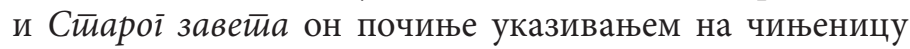
да ништа није било уобличено и да се смо дух Божији дизао над водама (Мојс. I: 2). У апокрифном поимању како раја тако и пакла реке су неизоставни елементи. У Првој кюизи Мојсијевој се јавља мотив река у Едемском врту који ће у апокрифној слици бити додатно развијен:

\footnotetext{
У ведским митовима можемо видети да почетак стварања света представљају примогенетске воде, као код грчког филозофа Талета, или тама застрта празнином која одговара Хаосу из Хесиодове Теоїонје, или бесконачном грчког филозофа Анаксимандра. То је, као и у ведама, праисконска празнина која је претходила митским теогонијама, из времена када још није било реда међу природним елементима. (Драгојловић 2008: 29)
} 
„У Едему је извирала река и натапала је врт. Оданде се гранала у четири крака. Првом је име Фисон, а протиче свом земљом евилском у којој има злата. Злато те земље је добро, а има онде и бдела и оникса. Другој реци је име Геон, а протиче кроз сву земљу хуску. Трећој реци је име Хидекел, а тече на исток од Асирије; четврта је Ефрат“ (Мојс. II: 10-15)

У апокрифној представи раја представљене су, такође, четири реке, али којима тече мед, млеко, вино и уље и на којима су смештени многи праведници. У паклу, пак наилазимо на ватрене реке, реке смоле у којима се муче грешници:

„И одмах дођоше херувими и серафими и 400 анђела и понеше Пресвету на јужну страну. И отуд истицаше река огњена. И стајаше у њој много народа, мушкараца и жена: неки до прса, неки до грла, а други до врха“. (Јовановић 20056: 379)

Везивање мотива реке за подземни свет је било често и у митским представама. Значајно место у веровањима античких народа имале су две врсте воде, Летина вода заборава и Мнемосинина вода сећања и обе су се налазиле у паганском доњем свету. Први извор је, према веровању, доносио заборав и смрт, а други памћење који може осигурати бесмртност. (Драгојловић 2008: 35) У српској епској поезији познат је мотив воде са мистичним својствима. У једној од песама Вукове збирке (СНП II: 97) за реку воде Ступице се каже да „није здрава за јунаке“, док у песми Пјеваније Симе Милутиновића-Сарајлије (Пјеванија, песма бр. 7) се помиње „студено зелено језеро“ чије воде трују коње и јунаке. У народној традицији се веровало да на „оном“ свету влада жеђ, те се покојнику у источној Србији стављала тиква са водом у ковчег, коју ће понети умрлим прецима. Вода унутар тикве је сматрана водом заборава, којом покојник бива укључен у круг мртвих. Наведена перцепција оностраног света је 
потпуно другачија од хришћанске, али ипак и у новозаветној традицији проналазимо причу о сиромаху Лазару и жеђи грешног богаташа у паклу. И у погребном култу проточна вода, нарочито она у рекама, потоцима, игра важну улогу. Када се након погреба у реци пере одећа умрлога, обавезно се неки мањи део одеће, нпр. чарапа, марамица, намерно пусти низ воду. Тако се и вода која је била крај умрлога, на самртном одру, проспе у реку. Пролазак крај воде, просипање воде има важно значење као елемент одласка мртвога са света живих у свет мртвих. (Петровић 1999: 46)

Река и уопште водени простор (језеро, море) је у традиционалној култури сматрани су често за опасно ${ }^{10}$ место. Одлазак на воду у „невреме“ било је непожељно jep се сматрало да је станиште демона и бића другог света ${ }^{11}$. У песмама о злој свекрви, врхунац лошег понашања према снаји представљен је заповешћу девојци да иде на реку у пола ноћи, када река припада оностраном ${ }^{12}$ : „/Туђа мајка, зла свекрва,/ С вечер воде све пролива,/ У комшилук довикује/ Да у двору воде нема/“. При томе не треба заборавити да је вода у традиционалној култури амбивалентна и она може служити као апотропејон, док уз неправилно коришћење може и да науди.

Мотив реке у рају и паклу може да означава и границу, гранични простор, а такву перцепцију пронала-

10 Постоје предања о „смраду од вила“ у којима се верује да су воду виле осмрадиле и да је не треба пити.

11 Вода која је захваћена после заласка сунца није се уносила у кућу јер се веровало да у њој може бити демона. Постојало је и веровање да ноћу не треба пити воду на рекама да не би попили врага са њом.

12 „Јула мела равне дворе, дуњо, дуњо,/ Јула мела, љуто клела, дуњо ле,/ Проклет да су два девера, дуњо, дуњо,/ Што ме шаљу по ноћи, дуњо, ле,/ Да заватим ладне воде, дуњо, дуњо,/ Скобише ме љуте гује, дуњо, ле/ Попише ми чарне очи, дуњо, дуњо,/ Попише ми чарне очи, дуњо, ле“ 
зимо у многим митологијама. Гранична вода у египатској митологији је вода подземног Нила, у грчкој митологији воде подземног Ахеронта, док је у староиндијској митологији гранична вода је вода мора. (Драгојловић 2008: 36) Море се помиње у српским средњовековним апокрифима врло често и оно означава претежно простор смрти, боравиште ђавола или неког другог митског бића. У апокрифу

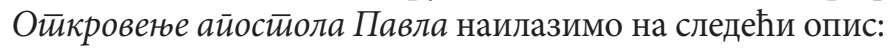

„И затим ми рече анђео: Прати ме, Павле, да ти покажем места грешних душа. И пођох на запад Сунца, и ту видех почетак небески, основан на великој реци воденој. И упитах анђела: Каква је ово река водена? И рече ми: Океан који окружује сву васељену. И стајасмо са оне стране океана. И видех да не беше светлости на оном месту, само жалост и туга“. (Јовановић 20056: 415-16)

Слично поимање појма мора налазимо у песми Жениgба Максима Црнојевића, где даљина девојке и одлазак „преко мора“ сугерише одлазак у онострано и непознато, што у традиционалној култури може резултовати кобним крајем: „Куд ме сила сломи преко мора/ на далеко четр'ес конака,/ преко мора да не видиш дома.“

2. Мотив змаја у српским средњовековним апокрифима и традиционалној култури

У апокрифу Борба арханђела Михаила са Сайанаилом (дужа верзија), змај спава на дну мора, где силази ђаво да би се боро са њим. Његов простор не припада ђаволу и он му није подређен што је веома важно увидети у апокрифној традицији. Море је и у неким народним песмама, приповеткама или обичајима означено као простор који је или граничан или припада оностраном, најчешће злим силама или смрти, док се у апокрифној грађи море и бића у њему се покоравају Богу. У апокрифу Варухово ойкровеґе представљен је хармоничан космогонијски систем који се огледа у нивоу воде, а који је условљен функционисањем митског бића тј. змаја: 
„И затим ме понесе анђео и путовасмо летећи тридесет и два дана. И показа ми поље превелико, које ум људски недоумева. И беше на пољу том гора веома висока и на њој лежаше змај од истока до запада. И сагињући се отпијаше од мора по лакат сваког дана. И земљу јеђаше као сено. И рекох ја Варух анђелу: Господару зашто пије змај овај од мора по лакат на дан и како не пресуши море када пије свакодневно?... -Јер ако не би пио змај овај, не би сувог било на земљи. Због тога заповеди тако Бог. И разгоре утробу змаја како би пио из мора по један лакат, тако да се нити прелије, нити пресуши“. (Јовановић 2005a: 119)

Д. Драгојловић је нагласио да треба разликовати две врсте змајоликог бића, једно је водено које може да прогута, задржи и из своје утробе избаци огромне количине воде, док је друго крилато, огњено биће, првобитно познато искључиво митологијама средњеазијских народа и Јевреја, а затим и код европских народа, пре свега Грка и Римљана. Други проучаваоци фолклора разликују змаја, који је претежно огњено биће, аждају, која се често везује за воду и алу, која је у веровањима повезивана са временским приликама. Ипак треба рећи да постоје својеврсна преплитања веровања о овим бићима те се змај једнако повезује и са воденим простором и са временским приликама иако је у описима најчешће огњено биће. Веровање да змајеви могу да утичу на временске прилике је очигледно проистекло из првобитне повезаности змаја и мора, као његовог станишта ${ }^{13}$.

Горе наведени текст апокрифа, можемо поредити са иранским митом о сукобу сила добра и зла, који се у науци врло често пореди са убиством демонског вука

13 Када настане опасна суша, народ је веровао да се змај негде у близини спустио, те се онда организују прогони змајева (Драгојловић 2008: 259) 
Фенрија из нордијског мита (детаљно описан у Сумраку $\delta о \overline{o в} a)$, а са друге стране са ведским митом о Индрином убиству змијолике Вртре, која је задржавајући воду у својој утроби претила да сушом уништи свет. Са иранским митом о сукобу сила добра и зла можемо поредити и опис космичког боја у старозаветним апокрифима и Јовановој Айокалийси између демонске војске предвођене Сатаном и небеске, предвођене арханђелом Михаилом, који се окончава савладавањем „аждаје, старе змије која је ђаво и Сатана“. (Драгојловић 2008: 260)

У народној традицији змајеви живе или на високим местима, попут планине Јастрепца или чардака „ни на небу ни на земљи“, или упећинама и рупама. За змаја, његово порекло, изглед и функцију су везивана многобројна предања и веровања. Тако се настанак змаја доводи у везу са змијом, те се верује да змија коју људско око није видело девет година постаје змај. Сретен Петровић сматра да је змија као симбол била повезана са лунарним календаром, плодношћу, култом предака и женским принципом, а да је култ змаја донео сасвим нову етапу у духовном развоју. Он сматра да се култ змаја поклапа се са настанком државне организације једнога народа, код које је патријархат основни модел морално-правног устројства заједнице, са доминантном соларном митологијом. Према предању „змај“ митолошко-морфолошки исходио од „змије“, као што је, према древном веровању, Сунце изишло из Ноћи. Змај се врло често појављује као спој неколико животиња, најчешће у форми египатске сфинге или античких кентаура, што се уметнички изражава у форми синтезе гмизавца и птице.

Змај је у српским старозаветним апокрифима, како смо напоменули, у служби Бога и он је најчешће представљен као заштитник водених простора: „И рече змај (Сатани): Сада си сатро све живо у мору, али пођи у дубину до крајњег дна... И борио се беше три часа док не збаци змаја са себе на четири миље“. (Јовановић 2005а: 106-107) 
У новозаветним апокрифима, под утицајем Ойкровењь Јована Богослова, змај бива доминантније повезан са мотивом ватре и злим силама. У народним веровањима змај је могао да буде представљен као зло биће, али и као заштитник и отац великих јунака. Тако се веровало да су јунаци који су се одликовали великом храброшћу и вештином, а којима је, историјски гледано, порекло било незнатно имају за оца змаја. У песми Милош Обилић змајски син наилазимо на следеће стихове: „Мој Милоше, моје миловање,/ Што гођ има Србина јунака,/ Свакога су одгојиле виле,/ А многога су змајеви родили,/ Ево првог тебе Обилићу,/ А другога Змај огњеног Вука,/ А трећега Рељу Бошнана,/ Змајева је и он породица,/ А четвртог Бановић Секулу,/ И њему је змај огњени бабо,/ А петог Бановић Страхиња,/ И њему је змај огњени бабо,/ А шести је Љутица Богдану,/ И њему је змај огњени бабо,/ А седмога Краљевића Марка,/ И њему је змај огњени бабо,/ Сваки има змајеву биљегу“. (СЕ3, 31, 1924: 111) У народној песми Сестира Леке кайейана, такође наилазимо на представу змајоликог јунака ${ }^{14}$ : „Но да видиш дивна Ђувеглије,/ Ђувеглије, Реље Крилатога!/ Није шала један крилат јунак!/ Није шала крила и окриље!/ (СНП II: 223) Стога је змајева амбивалентна природа очигледна у обе поменуте традиције, како народној, тако и религиозној апокрифној.

3. Мотив ђавола у српским средњовековним апокрифима и традиционалној култури

Једно од најупечатљивијих бића у апокрифној традицији, које у себи садржи синтезу библијског и народ-

14 О змајевитом пореклу јунака и њиховој перцепцији детаљно је писала Љиљана Пешикан-Љуштановић у књизи „Змај деспот Вук - мит, историја, песма“. 
ног предања јесте ђаво. Да бисмо представили фигуру ђавола, онакву, каква је она дата у апокрифима, најпогодније је поћи од његове физичке карактеризације и спољашњег изгледа. Слика ђавола у апокрифима није једнолична и типска. Она се мења од апокрифа до апокрифа, варирајући изглед, највероватније, у зависности од утицаја предлошка на самог писца. Ђаво у апокрифима није представљан као у Библији, али ни као у народним предањима и веровањима. Градећи фигуру ђавола, писци су правили својеврсну синтезу свега оног што су о њему чули или прочитали. Стога, тумачећи лик ђавола наилазимо на сложено наслојавање веровања, усмених и писаних предања, јеретичких прича, религиозних тумачења итд.

Детаљнији опис спољашњег изгледа ђавола дат је у обе верзије у апокрифа Борба арханђела Михајла са Сайанаилом. У краћој верзији се говори само о ђавољим крилима, док у дужој верзији наилазимо на следећи опис:

„Дужина његова, Владико, износи сто лаката, а ширина педесет лаката, а врат му је дванаест лаката, уста су му као трпеза велика, поглед као аспиде змије, и три главе су на њему. И Сотона смрт сеје и шкргуће зубима својим. И због тога ће ме, Владико, уплашити, и због тога ћу се оглушити о силу твоју, али опрости свом слуги“. (Јовановић 2005а: 101)

Овакав опис у поменутом апокрифу даје арханђел Гаврило објашњавајући зашто није дорастао задатку да се сукоби са Сатаном. Тиме се постиже снажан ефекат страха од „нечастивог“ на читаоца, а уједно се уздиже храброст арханђела Михајла, који ће поћи у борбу против Сатане. Као што видимо из наведеног описа, ђаво је приказан као врло велико биће. У новозаветном апокрифу О gруіом Христиовом доласку, где је описан Антихрист, затичемо врло сличан опис:

„Лице његово је мрачно, а власи главе његове оштре су као стреле, веђе његове као у дивљег вепра, десно око 
његово као звезда јутарња која излази, а друго као код лава, уста његова од лакта, зуби његови од педи, прсти његови као српови, стопе ногу његових две педи, а на лицу његовом пише Антихрист“. ( Јовановић 20056: 500)

Занимљиво је да је наглашена величина његових уста, а да су неки други делови тела непоменути. Могуће је да је такав поступак произашао из врло честе слике, како у књижевности, тако и у фрескосликарству, ђавола који гута грешнике ${ }^{15}$. Пакао је у апокрифима често независно приказан од ђавола. То није нужно његово станиште, већ само место које служи Богу за одлагање грешника, о чему ће касније бити речи. Овде је, пак, мотив уста поменут као веза са паклом, који често гута оне који су се огрешили о Бога. Веза ђавола са змијом је веома позната, али је не можемо сматрати симплификованом ${ }^{16}$, јер се ослања на различите традиције у апокрифима.

„Библијско постојање човека скоро да је неодвојиво од змије. У хришћанском предању о стварању света змија је била у истом простору са првим људима, Адамом и Евом, све до кључног тренутка њеног зближавања са отпадником небеског царства, ђаволом, што је допринело изгону из раја“. (Јовановић 2012а: 245)

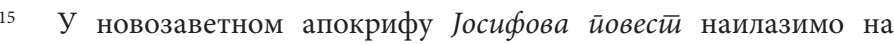
следећу молитву: „О Владико свих, избави ме страшног суда! Не дај ђаволу да ме пождере и својина његова да постане душа моја, јер видиш како се ђаво радује када чију душу узме, када тело чије невидљиво постане“. (Јовановић 20056: 191)

16 Змија је један од најистакнутијих, вишезначних и полифункционалних животињских ликова. Њена симболика је производ специфичне митолошке логике те су се у њој спојиле разнородне, често противречне и, рекло би се, међусобно опречне карактеристике. Она може да доноси зло и благостање, може да лечи или трује, да утиче на временске прилике, како позитивно, тако и негативно (изазива кишу и сушу, узрокује или спречава град), а њено убијање се сматра грехом, док у неким случајевима обећава опрост грехова, итд. (Гура: 208) 
Однос према змији је одувек био амбивалентан и зависио је од контекста. У Библији змија уједно представља и сарадницу ђавола, али и предсказање Христовог доласка или божије провиђење у Мојсијевом надметању са фараоном. Врло сличан однос према змији налазимо и у народној традицији. Змија спаја мушку и женску, ватрену и водену симболику, негативно и позитивно начело; отровна је и лековита, има штетна и апотропејска својства. (Гура 2001: 212) Змија уједно представља симбол плодности, подмлађивања и регенерације, мудрости, здравља, снаге, бесмртности и вечности (спирала/круг; ouroboros змија која гута свој реп), али поседује и хтонске црте (грех, Сатана, веза са светом мртвих и подземљем $)^{17}$.

У горе наведеном опису ђавола јасна је негативна конотација змије и ђавољег погледа, с обзиром на то да је аспида ${ }^{18}$ врло отровна змија, те такво поређење имплицира да је ђавољи поглед отрован. Опис очију је врло често имао функцију карактеризације неког лика у књижевности. Ако се ослонимо на народну изреку да су „очи огледало душе“, напомињање изгледа ђавољих очију даје увид и у то да је ђавоља душа отрована, повезана са смрћу. Мотиве повезаности ђавола са аспидом у апокрифима побројао је Т. Јовановић у свом раду под називом Мойив змије у айокрифима. Он напомиње да су у Књизи о Еноху аспиде представљене као чувари улаза у пакао ${ }^{19}$, док се у многим другим апокрифима са аспидом

17 Види: Делић (2012). „Змија, а српска - Змија у просторном коду“. Гује и јакрейи. Београд: Балканолошки институт САНУ

18 „Поред устаљеног израза змија среће се понекад и грчка реч аспида, која представља страшну змију отровницу. Ова се реч јавља кроз поређења у сликовитом предочавању страшних ликова у неколико старозаветних апокрифа“. (Јовановић 2012а: 251)

19 „И видех ад отворен и сужње и суд безмеран. И видех кључаре, стражаре адове, како стоје испред врата као аспиде велике, лица њихова као свећа искапана, као племе помрачено очи њихове, и зуби њихови обнажених до прса њихових“. (Јовановић 2005a: 144) 
упоређују негативно окарактерисани ликови, који имају зао језик ${ }^{20}$.

Троглавост, па и вишеглавост ђавола се често јавља. Таква представа највероватније води порекло из митске традиције, где су немани представљење са пуно глава. Вишеглавост се везивала и за хтонске животиње, те и то можемо повезати са ђаволом. Ђаво не припада ни свету људи, ни Богу, он егзистира у простору између, најчешће бавећи се ометањем људске везе са Богом. У Новом завети $y$ ђаво је често називан лажљивим и лицемерним, те се вишеглавост може тумачити и као сликовит приказ бића које има много лица. Т. Јовановић је у свом раду нагласио да је змија врло често приказивана као двоглава или вишеглава, те приказ ђавола са више глава може значити и симболичко поистовећивање ђавола и змије.

„Најчешће, змија у апокрифима нема неки посебан изглед. Тек понекад наиђе се на облик змије који припада митском уобличавању. Углавном су то бића са две или више глава, као у случају двоглавих змија у Хоgу Боі̄opoguи е йо мукама које пужу по извученом језику девојке са главом окренутом ничице, јер је чинила блуд. Двоглаве и веома љуте змије пуштају се у Постанищи Исуса Хрисйа йайи римском на људе како би појеле прса њиховим женама због раскалашног живота. Сличне змије спомињу се у краћој верзији Посланиие Исуса Хрисйа йатиријарху јерусалимском. Оне су такође двоглаве, али још и осед-

20 „Да би се истакло неверовање цара Елиуса у речи праведног Јова, користи се поређење са змијом и аспидом. У апокрифном Житиију йравеgної Јова каже се да Елиус није поштовао Господа, да је заволео змијску лепоту и тиме „имао отров као аспида на језику и у срцу“ (Јовановић 2005, 189). Слично је и у другој верзији апокрифа Како Давиg найиса Псалӣир, где Соломон пореди злу и језичаву жену са љутом лавицом, а њено чедо назива аспидом. (Јовановић 2005, 420) Иначе, истом синтагмом чеда аспидина означени су фарисеји на неколико места у Новом

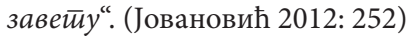


лане, и послате су на земљу да казне људе пијући им очи а женама груди“. (Јовановић 2012: 251)

Представу змија, које муче грешнике у „доњем свету“ и „пију“ им очи проналазимо и у народним лирским песмама. Таква слика је у народној традицији увек повезана са оностраним, демонолошким. Уз то, змије „пију“ очи онима који се оглушују о одређену врсту понашања патријархалне заједнице. Свако оглушивање о патријархалну норму, која је усклађена са веровањима заједнице резултира контактом са оностраним, које може бити кобно. Исти мотив змије, са специфичном улогом у апокрифима и народној традицији, имплицира везу између ова два домена стваралаштва тј. нужан међусобни утицај који би додатно требало проучити и испитати.

Повезаност ђавола са смрћу је веома чест поступак у књижевности, али не и нужан. Праведници, према предању немају „страшну и ружну“ смрт, док за грешнике смрт представља сусрет са ђаволом. У апокрифу O смриии Аврамовој наилазимо на следећи опис:

„И дође украшена смрт Аврааму. Видевши Авраам смрт да му дође, уплаши се веома и рече: Молим те реци ми ко си ти. Иди од мене. Када те видех, смути се душа моја у мени. Нисам достојан тебе. Ти си велики дух, а ја сам тело и крв. Због тога не могу трпети твоју славу, јер видим лепоту твоју која као да није од овог света... И рече смрт: Мислиш ли да је ово моја лепота, или да тако сваком човеку могу лепа бити?.. Ја сам горко име. Ја сам плач. Ја сам погибељ. Ја сам смрт која разлучује душе од тела... И скиде смрт лепоту са себе и показа трулеж своју. Имаше многе главе, а оне имаху змијска лица. Због тога многи од змије умиру. Друге главе имаху изглед коња. Тако многи од коња умиру. Друге главе су од огња. Тако многи од огња умиру“. (Јовановић 2005a: 411-12)

Сличност изгледа смрти и описа ђавола су очигледне. Вишеглавост и веза са змијом су у оба случаја присутна. 
Ипак, мотивски низ је у опису смрти проширен, те су придодати мотиви коња и ватре. Иако су сва три мотива (змија, коњ и огањ) појашњени као чести узроци смрти људи, те нас овај одломак може подсетити на народно предање, сва три мотива имају и сопствену сложену симболику, а спаја их одлика амбивалентности.

У новозаветном апокрифу Посланица Исуса Хрисйа йайријарху јерусалимском (дужа верзија) проналазимо, такође, врло интересантан опис ђавола, из перспективе Христа:

„И још ћу послати звер љуту, која има две главе, крила орловска, коњски реп, тако да ћете видети када буде појела ваша тела и чеда ваша пред очима вашим у Петров месец. И тада ћете почети бежати тамо и овамо и нећете се моћи сакрити од гнева мојега, јер су сва места моја. И све власи главе ваше прочитане су преда мном. И пашћете у моје руке и затим ћете почети бежати живи у гробове велегласно вичући и вапијући: Примите брзо, мртви, нас живе јер не можемо трпети ову љуту звер и гнев Бога сведржитеља“. (Јовановић 20056: 483)

Представа ђавола као синтезе више животиња је учестала. Он врло често има главу једне животиње (козе, мајмуна, змије...) или више глава, рогове, реп (било ког животињског порекла), ноге, које могу бити папци, копита или ноге живине и крила, чији број врло често варира. Понекад је ђаво антропоморфизован, али рогови и реп не изостају. $\mathrm{У}$ Кюизи ирророка Језекиља постоји опис анђела серафима, који су такође имали обличје саздано од више врста животиња и људске главе ${ }^{21}$. Према библијском предању, ђаво је поте-

21 „И видјех, и гле, силан вјетар/ долажаше од сјевера, и велики облак/ и огањ који се разгоријеваше, и око/ њега свијетлост, а усред огња као јака/ свјетлост/ Усред њега још четири животиње,/ које на очи бејаху налик на човјека;/ И у сваке бејаху четири лица, и/ четири крила у сваке;/ И ноге им бејаху праве, а у стопалу/ бијаху им ноге као у телета;/ и сијеваху као углађена 
као од анђеоског реда серафима, те постоји могућност да је сама библијска прича утицала и на шире представе о ђаволу. Уз то, веома лако се могу извести и паралеле са поимањем ђавола у народној традицији.

„У народним веровањима балканских Словена ђаво се различито описује. Преовладава схватање да је ово биће у људском облику, да има реп и рогове, козје ноге и да је црно. Заједничка особина је да се може претварати у разне облике, најчешће у животиње и људе“. (Раденковић 1997: 25)

Иако нису сва веровања и предања ${ }^{22}$ везана за ђаволе слична онима које видимо у апокрифима, преплитања ипак постоје. Претварање ђавола у различите ликове људског и животињског света једна је од таквих особина. Ђаво се у апокрифима претвара у различите облике, како би обмануо и навео људе на зло. Та његова особина вероватно проистиче из библијске традиције, у којој се ђаво претвара у змију и обмањује човека. У апокрифним причама имамо две верзије ђавоље преваре. У апокрифу Књиїа о Аgаму и Еви ђаво обмањује не само људе, већ и саму змију, за коју смо рекли да је била посебна миљеница божија: „И ђаво се претвори у анђеоски изглед и дође веома светао певајући песму анђеоску, као анђео и рече ми..." (Јовановић 2005а: 73) Док у апокрифу Сйварағье свеий ђаво, пак, сам узима обличје змије и вара Еву.

У другим апокрифима долазимо до много сложенијих образаца преваре. Један од најупечатљивијих представа

мјед./ И руке им бјеху човечије под/ крилима над четири стране, и лица/ им и крила бијаху четири стране/... А лице бијаше у све четири лице човечије и лице лавово с десне/ стране, а с лијеве стране лице волујско/ и лице орлово у све четири стране“. (Јез 1: 4-10)

22 Какав је био опис ђавола у народној традицији, лако можемо закључити и на основу назива, које је побројао Раденковић, нпр. рогати, репати, кусореп, копитар, Роми Даба, крив-ђаво, брадати, црномудиле, вран, вранић, најежник, онај матори, наказ паклена, неман, онај са црвеном капом... (Раденковић 1997: 21) 
ђавоље метаморфозе проналазимо у апокрифу Жийије u йоgвизи ирравеgноїа Јова, јер у њему ђаво неколико пута мења свој лик, зарад постизања преваре. Апокриф који се ослања на старозаветну причу о праведном Јову, који је и у свим тегобама остао одан верник Богу, била је врло подесна за апокрифну интерпретацију, стога што је један од главних актера приче ђаво, који се може представити читаоцу на врло занимљив начин. Ђаво се у овом апокрифном житију јавља неколико пута и готово сваки пут има друго обличје. У првом делу приче, ђаво је поистовећен са идолом, који подразумева било које божанство са материјалним обличјем, осим јудејског Јахве. Након тога, ђаво се претвара у луталицу сиромаха, који тражи на Јововим вратима хлеб. Епизода коју смо управо описали веома је специфична и може се тумачити на различите начине.

У народној традицији, појављивање просјака или сиромашне луталице на вратима куће често је означавала долазак оностраног. Даривање потенцијалног божанства требало је да осигура благостање дома. Јов се у апокрифној причи не оглушава о стару традиционалну норму, али он не дарива добар хлеб, већ загорео. Дељење хлеба са неким, уопштено у заједницама је означавало присан однос припадника одређене заједнице. (Страхов 1991) Уколико желимо да сагледамо овај поступак из контекста новозаветне традиције, довољно је поменути да је последњи заједнички чин Христа и његових ученика било дељење хлеба. Осим тога, ритуална пракса која је установљена у цркви, такође, садржи обред дељења хлеба, који симболише тело Христово, међу члановима заједнице. Уз то, хлеб је као ритуални предмет саставни део многобројних обреда у народној култури балканских Словена. Он је део многих обреда који прате човека од рођења до смрти. Код Срба и Бугара налазимо више магијских поступака у којима се кроз бајање, или без њега, неким замишљеним бићима дарује хлеб. По правилу та 
бића су у женском роду (чума, баба Шарка, вила...), а даривање хлебом је требало да се осигура мир између оностраног бића и људске заједнице. (Раденковић 1996) Хлебом је вршено својеврсно подмићивање ${ }^{23}$ оностраних сила, како не би нападале људску заједницу. Хлеб је могао да представља одређен жртвени принос вишој сили, коју треба умилостивити ${ }^{24}$. Уколико се из тог контекста осврнемо на Јовов поступак у апокрифу, можемо га тумачити као симболичан раскид са силом зла:

„И узе хлеб загорели и даде му говорећи: Овако говори Господар мој Јовав: Никада не поједи из руку мојих хлеб пошто сам се одрекао тебе. И тим више, јер датох ти такав хлеб и криво ми је јер дадох ђаволу, а њему није достојно дати“. (Јовановић 2005а: 175)

Из наведеног текста нам је јасно да Јов није смео да се оглуши о институцију гостопримства ${ }^{25}$ и милостиње, која је на високој позицији, како у хришћанској, тако и у традиционалној култури. Он надмудрује ђавола и пружа

23 У сврљишком Гулијану о Бадњој вечери, старица у улози првосвештенице, на огњишту на којем гори бадњак приноси хлеб звани „Божји колач“ и дижући га три пута увис изнад огња изговара нарочите речи: „На ти Боже колач, а ти мени здравље“. (Раденковић 1996).

24 Смисао феномена жртвовања је да се једна заједница овим ритусом супротстави сили деструкције и нереда. На тај начин је стварана конструктивна и интегративна, заштитна снага друштва. (Петровић 1999: 16)

25 Однос према странцима у нашем народу се најјасније испољава у обичају гостопримства. Институција гостопримства је веома распрострањен, мада не и општи обичај, како то покушава да прикаже В. Чајкановић (328, 1-4. упор. 315, 225 и др.). О његовом пореклу много се писало и расправљано. Неки истраживачи сматрају да је настанак овог обичаја повезан са алтруистичким осећањима, други са љубопитљивошћу и жељом за новим сазнањем (Џ. Л. Гериг), трећи са развојем међународног саобраћаја (О. Шрадер), четврти са религијским схватањем (Е. Вестермарк) итд. (Бандић 1980: 353) 
му милостињу, али недостојну правог утврђивања везе, која се иначе остварује тим чином. У ђавољем одговору Јову уочавамо и присуство подразумеване хришћанске симболике хлеба као тела: „Овако реци вратарице Јоваву: као што је овај хлеб огорео, тако ћу ја сажећи тело твоје“. (Јовановић 2005a: 175)

Уколико је хлеб могао да представља жртву у обредима, Јовово неправилно приношење жртве је морало бити кажњено. Очигледно је да је библијска прича у апокрифу добила дубљу мотивацију лика ђавола. Изношењем лоше жртве и неостваривањем везе са ђаволом Јов на себе управља бес ђавола. Нешто касније, у истом тексту, ђаво се преображава у пекара, који остварује одређену размену са Јововом женом. Овог пута, жена тражи хлеб од ђавола/пекара и добија га тако што јој ђаво одсеца сву косу са главе. Коса је један од делова тела за који се у патријархалним заједницама веровало да и након одвајања од тела остаје у симпатичкој вези са својим власником. Према коси су се жене посебно опходиле, а њено држање је симболисало статус жене у заједници. Коса је сугерисала да ли је жена удата или да ли је спремна за удају. Утицајем хришћанства, коса је сматрана женским атрибутом који заводи, те се коса удате жене скривала од мушких појединаца. (Радисављевић 2007: 2) Симболичко значење поступка Јовове жене је врло важно. Ако се за косу веровало да је у вези са власником након одсецања, давање косе ђаволу би означавало трајну везу са њим. Осим тога, ако се осврнемо на Нови завети и молитву коју изговара Христос, за хлеб се моли Богу, док је описана ситуација обрнута. Тражење хлеба од ђавола и успостављање трајне везе са њим резултује обешчашћивањем жене у традиционалном контексту.

Када се говори о вези српских средњовековних апокрифа и традиционалне културе, веома је тешко утврдити порекло одређених мотива и сижеа, као и на ком месту 
се они први пут појављују. У овом раду нисмо настојали да утврдимо порекло одређених слика, које се јављају и у апокрифима и у делима народног стваралаштва. Намера нам је била да укажемо на аналогију која постоји и да дамо евентуално тумачење, које ће нам помоћи у одгонетању значења одређених апокрифних слика. Имајући у виду да су апокрифи настајали под снажним утицајем ранохришћанских текстова који су развијањем хришћанске мисли одбацивани или прихватани, свесни смо основног предлошка на коме они настају. Ипка, врло је важно узети у обзир да су одређени елементи народне традиције, у маниру преписивања средњовековних књига, свакако могли да доспеју у апокрифна дела, као што су и апокрифне слике, које је народ могао да чује у цркви, кроз проповеди или читање самих апокрифа, улазиле у народну представу о оностраном. Сматрамо да уочавање таквих веза између ове две врло комплексне традиције је од пресудног значаја за правилно тумачење садржаја, у оба случаја.

\section{Извори и литература:}

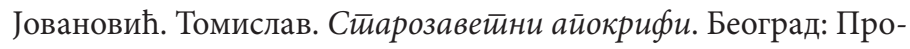
света, 2005.

Јовановић. Томислав. Новозавейни айокрифи. Београд: Просвета, 2005.

Библија. Београд: Свети архијерејски синод Српске православне цркве, 2014.

Караџић, Вук Стефановић (1987). Срйске нароgне ӥјесме I. Београд: Просвета-Нолит

Ајдачић, Дејан. „Демони у словенским књижевностима : књижевнотеоријска типологија на примеру источноевропских у јужнословенских књижевности“. 3борник Майище срииске за славистиику. Нови Сад: Матица српска, (1997): 135-150.

Богдановић, Димитрије. Истиорија сйаре срйске књижевностии. Београд: Српска књижевна задруга, 1980. 
Гура, Александар Викторович Симболика животичюа у словенској нарояној йраяищији. Београд: Бримо, 2005.

Делић, Лидија. Гује и јакрейи: кюижевности и кулитура. Београд: Балканолошки институт САНУ, 2012.

Детелић, Мирјана. Мит̄ски ӣрост̄ор и ейика. Београд: Српска академија наука и уметности, 1992.

Драгојловић, Драгољуб. Паїанизам и хришћансӣво у Срба. Београд: Службени гласник, 2008.

Ђорђевић, Тихомир. Наш народни животи. Београд: Издавачка књижарница Геце Кона, 1931.

Ђорђевић, Тихомир. „Баво у нашем народном веровању“. Книжевна истиорија. Београд: Институт за књижевност и уметност, 2015.

Елијаде, Мирча. Слике и симболи. Београд: Factum издаваштво, 2015.

Елијаде, Мирча. Свет̄о и йрофано. Београд: Алнари, 2004.

Јовановић, Томислав. „Траг апокрифа о борби са ђаволом у српској народној књижевности“. Кюижевности и језик. XLIII, 3-4, Београд, 1995.

Колаковски, Лешек. Невоље с ђаволом. Београд: Логистика, 2007.

Николов, Ено. Айокрифна титиерайира. Софија: Народна култура, 1948.

Нола, Алфонсо. Баво. Београд: Клио, 2008.

Петканова-Тотева, Донка. Айокрифи. Софија, 1981.

Петканова-Тотева, Донка. „Апокрифна литература и фолклор“. Наука и изкустиво. Софија, (1978): 171-183.

Петровић, Сретен. Срйска митиолоїија. Ниш: Просвета, 2000.

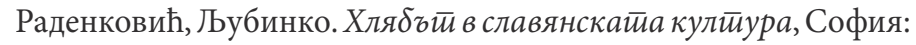
Етнографски институт с музей - БАН, (1997): 145-155.

Раденковић, Љубинко. „Представе о ђаволу у веровањима и фолклору балканских Словена“. Зборник Майице срйске за славистиику. Нови Сад, (1997): 15-38

Раденковић, Љубинко. „Словенска народна демонологија на синхроном и дијахроном плану“. $3 \delta о р н и к ~ М а \overline{и щ е ~ с р и ̆ с к е ~}$ за ставистиику. Нови Сад: Матица српска, (2013): 9-23.

Расел, Џефри. Прини, йаме. Београд: Понт, (1995): 17-103 
Страхов, Александар Борисович. Культ хлеба у восточных славян : опыт этнолингвистического исследования. Минхен: Ото Зангер, 1991.

Ћоровић, Владими. Светии Сава у нароgном йреgағуу. Београд: Народно дело, 1990.

Чајкановић, Веселин. „Баво“; „Демони болести“. Сйара срӣска релиїија и мит̄олоїија. Београд: Српска књижевна задруга, 1994.

Isidora Ana Stambolić

\section{RELATIONS BETWEEN TRADITIONAL CULTURE AND AND SERBIAN TRANSLATIONS OF THE APOCRYPHA IN THE MIDDLE AGES}

\section{Summary}

In this paper we will endeavor to point to potential analogies that can be observed between certain textual segments of Serbian Medieval Apocrypha and traditional culture. Because of the scale and complexity of the subject, we did not try to list and analyze all such existing connections. We instead selected a few memorable and convenient motifs for the clear indication of the connection of the two mentioned traditions. And so we have decided to present a thesis in connection with space, the motif of the dragon, the snake and the Devil, that are represented and evoked in a similar way in both the apocrypha and folk tradition.

Key words: apocrypha, traditional culture, space, the devil, snake, dragon 